\title{
On the Differential Market Reaction to Dividend Announcement: Evidence from an Emerging Equity Market
}

\author{
Usman Bashir, Dr. Syed Zulfiqar Ali Shah, Muntazir Hussain \\ Faculty of Management Sciences \\ International I slamic University Sector H-10, Islamabad, Pakistan \\ Email: bbashir.usman@gmail.com
}

\begin{abstract}
The corporate finance literature for market reaction to dividend announcements reports mixed results: some of studies support a positive response of markets as a result of dividend announcement whereas some report negative. This study is an attempt to investigate the heterogeneous market reaction to dividend announcement for 73 firms listed in the Karachi Stock Exchange. We investigated this phenomenon with a novel methodology using both the event study and multivariate regression for the possible effects of firm-specific factors associated with dividend announcements. We report that the market reaction is one-sided as the majority of companies in the sample are with positive CAR for the given period. We cannot ignore the importance of firm-specific factors that have an effect on the dividends but we conclude that the majority of companies in the sample period portray a positive CAR and the market reaction is positive.
\end{abstract}

Key Words: Dividend Announcement, Cumulative Abnormal Returns, Firm-specific Factors, Market Reaction

JEL Classification: G12, G14, G32

\section{Introduction}

Investors are always interested in optimizing their earnings and continuous search of optimal investments on the basis of technical and signalled information. Healthy dividends depict the profitability of the company and good investments made by the management. The relationship of dividend and stock prices has been under debate of most researchers. Dividend announcement conveys the information about the future earnings of the company, i.e. it conveys a signal to the investors of how the firm will perform in the future. One of the common assumptions is that market is not efficient, whereas the dividend information content sends a signal to investors. The finance literature has proved that the 
stock prices of a company change after the announcement of dividends (Bhattacharya, 1979, 1980; John \& William, 1985; Miller \& Rock, 1985). Managers intentionally or unintentionally send a message to external investors about the pattern of firm's future earnings and value by announcement of cash dividends (Miller \& Modigliani, 1961). Most of researchers have focused on the influence of earning information on stock dividends by applying the event study to capture the possible effect. J in (2000) suggested that there may be other firm-specific factors affecting the stock prices other than dividend announcements.

The concept which explains the relationship of stock price and information content of dividend is given by the dividend signalling theory proposed by Miller and Rock (1985), free cash flow theory (Bhattacharya, 1979, 1980; John \& William,1985; Miller \& Rock, 1985), free cash flow hypothesis given by Jensen (1986) and Agency Cost theory forwarded by Easterbrook (1984). The discussion in these theories mainly states that changes in firms dividend policy significantly affects the share prices of the respective firm. The dividend announcement, which might be a result from any of the three theories, acts as a transmitting channel which signals the future earnings of the firm to investors. Higher dividend figures represent the strength of the company in the context of producing higher earnings in future and vice versa. Indirectly, when a firm announces higher dividends, the stock prices of the company will also increase - this statement has been substantiated by the mixed empirical results in literature of e.g. Jin (2000); Mitra \& Owers (1995); Healy \& Palepu (1988). The dividend announcement plays a role as a signal to investors; in case of a dividend increase it portrays a positive signal that future earrings will increase, while a decrease gives a negative signal to investors that future earnings will deteriorate. Basically, it is the way of communication or a channel via which the firm communicates with the investors this was first identified by Cooper et al. (2001), who explained various ways in which firms communicate with investors some of which are earning announcements and dividend announcements.

This paper is an attempt to investigate empirically whether the stock prices change after the announcement of dividends. Does the information content hypothesis given by Miller \& Modigliani (1961) holds for Pakistani firms? Furthermore, the main objective will be to check the relationship of firm-specific factors and whether the dividend announcement is 
influenced by these factors. This study has significance for both the corporate manager as well as for the investor. The managerial importance of this study lies in the relationship of a positive dividend announcement and the firm value. As we have stated, the management can portray positive signals to investors by announcing high dividends. Higher dividends are seen as the best managerial application of skills and investing in optimal and positive NPV projects leading to higher yields, which creates a healthy perception in the minds of investors that the firm is moving towards shareholder wealth maximization and value creation.

The investigation proceeds in two ways. We are applying diverse methodology in terms of the event study by incorporating firm-specific factors which enhance the robustness of the empirical results of the event study. Using the event study methodology alone would lead to spurious results due to the association of firm-specific factors which might distort the actual findings. Secondly, the sample is divided into two groups: first, the full sample is considered, then it is divided into two groups having positive and negative CAR, for the possible effect of firm-specific factors. This paper is structured into five sections. Immediately following Introduction in Section 1 is Section 2, which outlines valuable literature in this area. Section 3 describes the nature of data and methodology. Section 4 presents the empirical results, and Section 5 contains concluding remarks regarding the results in section 4 .

\section{Literature review}

The dividend announcement and its common perception in the minds of investors are often debated in the corporate finance literature. In literature, we found both supportive and contradictory views of the information content of dividends. Fama (1970) applied the efficient market hypothesis to stock market and divided the information efficiency in three categories; a weak form of efficiency, a semi-strong form of efficiency and a strong form of efficiency. He further explained how the information is reflected in stock prices. A similar concept is found in studies like Keith Cuthbertson (2005); Reilly (2006). A contradictory side, like Miller and Modigliani (1961), investigated this concept and concluded that the dividend announcement has no impact on the firm returns and the dividend information content hypothesis is irrelevant. They further argued that this phenomenon has no impact on stock prices of firms 
under the assumption that the market is perfect and firms invest with fixed schedule. Rubinstein (1976) tested this context and concluded that the dividend information content is neutral and it has nothing do with the increase or decrease of the stocks return. Kamstra (2000) supported Miller and Modigliani (1961) and concluded that the dividend announcement has nothing to do with the change in prices of the stock. Gordon and Shapiro (1956) provided an view opposing that of Miller (1961) - they concluded that the dividend announcement significantly affects the stock prices and firm returns. Handjinicolaou and Kalay (1984) studied this phenomenon and concluded that it seems that the current dividends are affecting the future dividend changes and stock prices. Similarly, a more recent study, Deangelo and Deangelo (2006), found that the information content of dividends is highly relevant.

A lot of researchers (Healy and Palepu, 1988; Nissim \& Ziv, 2001; Michaely et al., 1997; Dyl \& Weigand, 1998; Grullon et al. 2002; Koch \& Sun, 2004; Fargher \& Weigand, 2009) agree that the information content of dividends has a significant impact on stock prices. They used the CAR to conduct the analysis. They found a positive and significant relationship between the CAR and profitability of the firm and its stock prices. What they fail to reject is that there is a negative relationship between the CAR and risk. Frankfurter and Wood (2002), Bozos, Nikolopoulos and Ramgandhi (2011) studied the phenomenon in two steps. First, the authors developed the CAR, and second, they regressed the CAR on various sets of variables. They concluded that the firm produced a positive and significant CAR at the announcement dates. In the second part, they found a significant and positive relationship between managerial ownership variable and information content of dividend. They found all firm specific variables significant and positive in relationship with CAR. Other studies (Boehem \& Sorescu, 2002; Brav et al, 2005; How, Ngo \& Verhoeven, 2011) tested the reaction of market investors to dividend announcements. The stock prices increased and they validated the signalling theory. Fama (1969) studied the phenomenon and concluded that the information content of dividend is significant. The dividend gives a signal to market investors about the future trends of stock prices moving. The study divided the data into positive and negative abnormal return and analysed them in the form of the event study. The significant positive CAR confirmed a positive 
response of market to dividend announcements. The overall results are in accordance with the information content of dividend hypothesis that the market investor can get a positive or a negative signal as a response of a dividend announcement. In an additional study, utilizing quarterly information, Pettit (1972) suggested that dividends convey sufficient signals to market investors. But the question is how the market takes time to adjust the signal to represent the true efficiency; if the signal that is sent to the market in the form of dividend is efficient and how much time it would take to adjust with the true value of stocks. He suggested that the dividends convey signal in excess of what the market perceives. Bhattacharya (1979), holding the perfect information efficiency, claimed that investors have capability to assess the inner news of firm. They use various tool to assess the firm profitability, risk and real worth of business. The management uses the dividends as a signalling tool to give the signal about the real worth of the firm to the external market.

John and Williams (1985), Miller and Rock (1985), the slightly updated and modified versions of the dividend information content hypothesis, were incorporations of the cash flow concept. The dividend announcement affects the cash flow in near future or present. This activity is intentional in nature; however, management do this by incurring some cost to give a signal to market investors and shareholders. Jensen (1986) suggested that the free cash is the main determinant of the stock prices increase and decrease in the case of information content of dividend. The dividend would be paid in the case of free cash flows where the cash is in excess of the cash required for the investment projects. The abnormal response of stock prices would only be observable when there is an unexpected dividend announcement. Easterbrook (1984) incorporated the agency cost concept into the phenomenon. He argued that keeping the shareholder separated from the management concept sometimes encourages misuse of funds by the management. In the context of agency theory hypothesis, the reaction of stock prices would be negative when dividend announcement occurs. The research yielded somewhat interesting results regarding the dividend initiation and dividend omission. Studies like Mitra and Owners (1995) argued that that the increased dividend announcement has a positive effect on the stock returns. The study by Eades and Kim (1985) suggested that the decreasing dividend announcements have a negative 
impact on the stock returns. The emerging markets like Malaysia reacted the same as in the study of Mitra and Owners (1995); Hess and Kim (1985). They concluded that the increasing dividend has a positive and decreasing dividend has a negative effect on the stock prices. Kao (1994) studied the unexpected dividend announcements and information content of dividend and concluded that dividend information sends significant signals to market investors. Further, he suggested that the management take valuable information to confirm their expectations in future and present scenario.

\section{Data and methodology}

The data is obtained from Balance Sheet Analysis files (BSA) compiled by the State Bank of Pakistan (SBP) Statistics and DWH department. Firmspecific variables data is obtained by the BSA files, the stock prices data is taken from Business recorder for 73 companies on the basis of final dividend announcement dates in the year FY011. The methodology is divided into two parts: the first is to estimate the cumulative abnormal returns using the event study to find out whether there is any effect of the dividend announcements on the stock prices of the firms, these test are suggested by Thompson (1985); Johnston, (2007). The abnormal returns are calculated by expected returns by the market model; the equations follow:

$$
\begin{gathered}
r_{e}=\alpha_{0}+\delta_{1} r_{m} \\
C A R_{t}=\sum_{t-1}^{0} A R_{k t}
\end{gathered}
$$

Where for equation (1) $r_{e}$ is the expected return, $\alpha_{0}$ is the intercept or constant, $r_{m}$ is the return of market and $\delta_{1}$ is the slope. After this step we calculate the abnormal returns and the cumulative abnormal returns as in equation (2) and consider the event pre and post window to be 60 and 10 days respectively to identify the effect of such announcements on the firm's stock prices. The second part of the methodology is to check whether the CARs (calculated in equation 3) calculated are effected by any other firm-specific factors; for this purpose firm-specific factors are incorporated which will enhance the robustness of the empirical results of the event study. If only the event study methodology was applied, the results would be spurious due to the association of other factors which 
might distort the actual findings. Secondly, we divide the sample into two groups: first the full sample is considered, then it is divided in two groups having a positive and negative CAR, for the possible effect of firm-specific factors. The regression equation will be as follows

$$
C A R_{i}=\alpha_{0}+\delta_{1} S Z E_{i}+\delta_{2} E V O L_{i}+\delta_{3} L E V_{i}+\delta_{4} D Y_{i}+\delta_{5} L I Q_{i}+\varepsilon_{I} i
$$

Where " $i$ " is the cross-section, $\alpha_{0}$ is the constant and $\delta_{1}$, $\delta_{2}, \delta_{3}, \delta_{4}, \delta_{5}$ are the coefficients of the explanatory variables. $C A R_{i}$ is dependent variable for i firms.

\subsection{Specifications of firm specific variables}

In the equation above, the explanatory variables are SZE which is the size of the firm. Similarly to Viswanath et al. (2002), we define the firm size as the natural logarithm of market capitalization; empirical work of Mougoue and Rao (2003) and Alpa and Dhanni (2005) document a reverse relationship between firm size and dividend payout. The EVOL is the volatility which is measured by the standard deviation of stock returns as studied by Rubin and Smith (2009), firms with net income more volatile distribute more dividends in order to send a good signal to outside investors - the relationship is expected to be positive; less volatile firms will be inferred as having a steady stream of cash flows leading to consistent dividends as compared to more volatile ones.

LEV is the leverage ratio of the firm. It is calculated as total liabilities as a percentage of shareholders equity, the signal is expected to be positive which may be due to two different aspects under the agency theory and signalling theory. According to Borokhovich (2005), the higher ratio leads to meeting financial liabilities which reduces funds for distribution. According to Ross (1977), the higher the debt ratio the more will be the firms value increased. DY is the dividend yield of firms, which is calculated as the total amount of dividend as a percentage of shareholders equity, the relationship with stock prices is ambiguous and may be positive or negative as documented by Belden, Todd and Knapp (2005) as well as Easstons and Sinclair (1989). LIQ is the liquidity of the firm; it is calculated as cash in hand divided by total assets; the firms having high liquidity are considered to give more dividends so the expected signal is hypothesized to be positive. It is hypothesised that if 
any of the explanatory variables is positively or negatively significant in equation 2, it can be deduced that it is not only the information content of dividend that affect cumulative abnormal returns but also other factors whichever is significant in equation 3 .

\subsection{Chow Test}

The latter part is to check if there is any difference between the firms having negative and positive CARs. On this basis the firms will be divided in two groups consisting of the whole sample. The CHOW test will be applied to check whether there is any significant difference between the above mentioned subgroups.

$F_{\mathrm{C}}=\frac{(S S f-S S p-S S n) / k}{(S S p+S S n) /(N-2 k)}$

where $S S f$ is the sum of square residuals of full sample, $S S p$ is the sum of square residuals of positive sample and $S S n$ is the sum of square residuals of negative sample.

\section{Results}

We have applied the event study methodology to calculate the cumulative abnormal return of all companies. As we have used 73 companies for the analysis, we could not report the table of cumulative abnormal returns. For the sake of brevity the cumulative abnormal return (CAR) table is not reported. The CAR has both positive and negative significant values as shown in figure 4.1. The positive and significant values of the event study before the event (Dividend announcement) indicate that the investors speculate on an increase in the future prices of stock and are engaged in speculative activities. For some companies, the CARs were negative after the event of announcement of the dividends, which indicates the stock returns have decreased after the announcement of the dividends. Some companies that report positive and significant CAR after the dividend announcement are consistent with the idea that the stock prices increases as dividends are announced. For the sake of further analysis, the CAR are categorized as a full sample and further into two subgroups. The first category includes CAR of all companies. We report it as full CAR "F". The second group includes the positive CAR of all companies and we 
report it as positive CAR "P". The third category includes the negative CAR as we report as negative CAR " $\mathrm{N}$ " in Table 4.1 and Table 4.2. For each category of CAR, we have estimated the separate equation where we kept the CAR as the dependent variable and firm-specific variables are independent variables. We report the multivariate cross sectional regression results in table 4.1 and table 4.2 .

Before discussing the basic results of the multivariate regression model, we present the overall explanatory power of the model and overall significance of the model. We report the two important elements as Rsquared values and F-statistics. The values reported in the bottom of table 4.1 and 4.2 are the R-squared values. The R-squared value in the case of all regression is comparatively low; however, the good thing is that the model is overall significant as the F-statistics reported are significant in all cases of regression equation.

Figure 4.1 Pictorial presentation of average CARs of firms

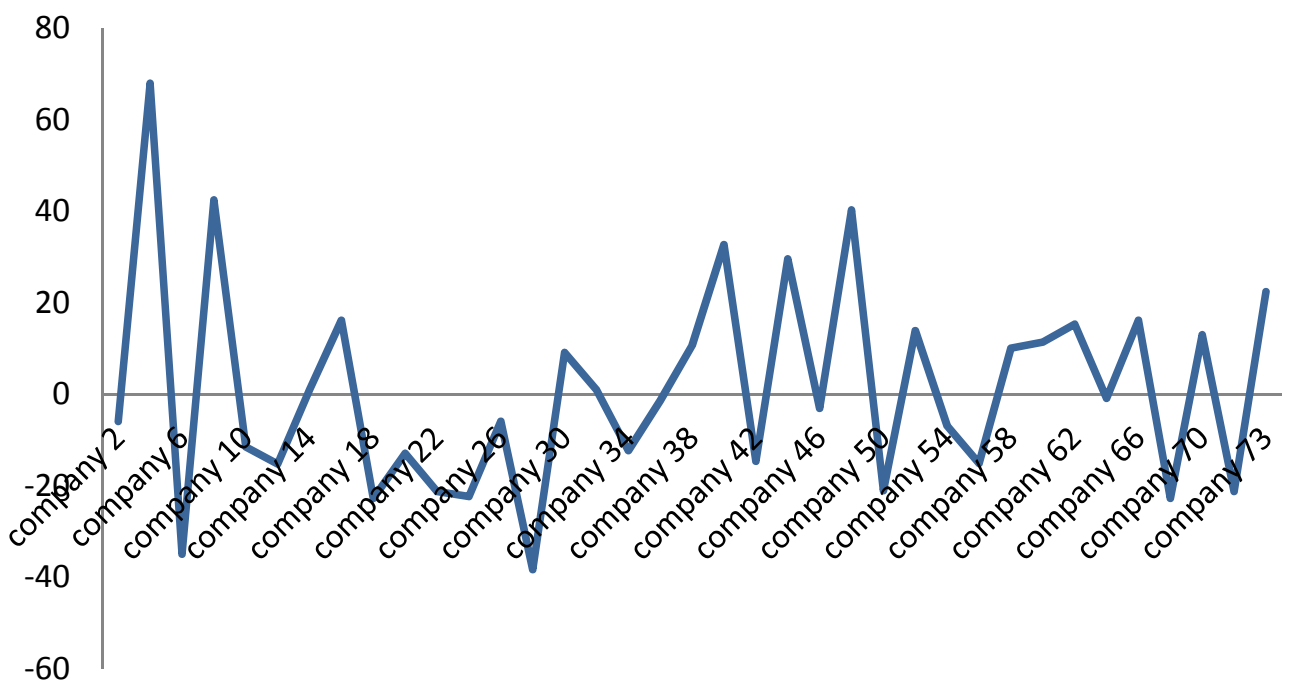

Source: authors' processing 
Table 4.1 Results of Multivariate Cross-Sectional Regressions for CAR 1, 2 and 4

\begin{tabular}{|c|c|c|c|}
\hline \multirow[t]{2}{*}{ Variable } & \multicolumn{3}{|c|}{ CAR 1} \\
\hline & $\mathbf{F}$ & $\mathbf{P}$ & $\mathbf{N}$ \\
\hline \multirow[t]{2}{*}{ SZE } & -0.0037 & 0.0532 & -0.0332 \\
\hline & $(0.2340)$ & $(0.5610)$ & $(0.1940)$ \\
\hline \multirow[t]{2}{*}{ EVOL } & -0.0453 & -0.0651 & 0.0014 \\
\hline & $(0.055)^{* *}$ & $(0.1940)$ & $(0.5610)$ \\
\hline \multirow[t]{2}{*}{ DY } & 0.1350 & -0.2510 & -0.0392 \\
\hline & $(0.023) * * *$ & $(0.2624)$ & $(0.1497)$ \\
\hline LEV & $\begin{array}{c}0.3020 \\
(0.3185)\end{array}$ & $\begin{array}{c}-0.0146 \\
(0.0897) *\end{array}$ & $\begin{array}{c}0.1340 \\
(0.2931)\end{array}$ \\
\hline \multirow[t]{2}{*}{ LIQ } & 0.0144 & -0.0346 & -0.0022 \\
\hline & $(0.050)^{* *}$ & $(0.058) * *$ & $(0.3924)$ \\
\hline $\mathbf{R}^{2}$ & $24.63 \%$ & $13.97 \%$ & $17.30 \%$ \\
\hline $\begin{array}{l}\text { F-STAT } \\
\text { CHOW }\end{array}$ & 4.4170 & $\begin{array}{c}2.8160 \\
10.0168 * * *\end{array}$ & 3.4210 \\
\hline \multirow[t]{2}{*}{ Variable } & \multicolumn{3}{|c|}{ CAR 2} \\
\hline & $\mathbf{F}$ & $\mathbf{P}$ & $\mathbf{N}$ \\
\hline \multirow{2}{*}{ SZE } & -0.0335 & 0.0113 & -0.0017 \\
\hline & $(0.1352)$ & $(0.2370)$ & $(0.3215)$ \\
\hline \multirow[t]{2}{*}{ EVOL } & -0.0016 & -0.0020 & 0.0035 \\
\hline & $(0.3215)$ & $(0.4891)$ & $(0.2931)$ \\
\hline \multirow[t]{2}{*}{ DY } & 0.0231 & -0.3126 & 0.0163 \\
\hline & $(0.054)^{* *}$ & $(0.098) *$ & $(0.2561)$ \\
\hline LEV & $\begin{array}{c}0.2310 \\
(0.3215)\end{array}$ & $\begin{array}{c}0.0018 \\
(0.2163)\end{array}$ & $\begin{array}{c}0.0632 \\
(0.2763)\end{array}$ \\
\hline \multirow{2}{*}{ LIQ } & 0.0772 & -0.1555 & 0.0233 \\
\hline & $(0.051)^{* *}$ & $(0.6145)$ & $(0.2340)$ \\
\hline $\mathbf{R}^{2}$ & $27.35 \%$ & $35.12 \%$ & $14.17 \%$ \\
\hline $\begin{array}{l}\text { F-STAT } \\
\text { CHOW }\end{array}$ & $\begin{array}{r}4.8650 \\
7.963 * * *\end{array}$ & 3.7690 & 2.6250 \\
\hline \multirow[t]{2}{*}{ Variable } & \multicolumn{3}{|c|}{ CAR 4} \\
\hline & $\mathbf{F}$ & $\mathbf{P}$ & $\mathbf{N}$ \\
\hline \multirow[t]{2}{*}{ SZE } & -0.0039 & 0.0002 & -0.0161 \\
\hline & $(0.1314)$ & $(0.2163)$ & $(0.2931)$ \\
\hline \multirow[t]{2}{*}{ EVOL } & -0.0020 & -0.0017 & -0.0032 \\
\hline & $(0.3215)$ & $(0.2579)$ & $(0.2693)$ \\
\hline \multirow[t]{2}{*}{ DY } & 0.0295 & -0.5630 & 0.1680 \\
\hline & $(0.051) * *$ & $(0.057)^{* *}$ & $(0.1790)$ \\
\hline \multirow[t]{2}{*}{ LEV } & 0.0231 & 0.0024 & 0.1320 \\
\hline & $(0.053) * *$ & $(0.1213)$ & $(0.2459)$ \\
\hline \multirow[t]{2}{*}{ LIQ } & 0.0169 & -0.0054 & -0.0022 \\
\hline & $(0.5610)$ & $(0.1940)$ & $(0.1352)$ \\
\hline $\mathbf{R}^{2}$ & $15.62 \%$ & $26.30 \%$ & $27.31 \%$ \\
\hline F-STAT & 3.4230 & 2.3150 & 4.4360 \\
\hline CHOW & $7.134 * * *$ & & \\
\hline
\end{tabular}

P-values are clustered in parenthesis*,** and*** indicates values at $10 \%, 5 \%$ and $1 \%$ significance level. $\mathrm{F}, \mathrm{P} \& \mathrm{~N}$ in the second row of column are the Full, Positive and Negative CAR respectively.

Source: authors' processing 


\subsection{Results of Multivariate Cross-Sectional Regressions for CAR 1, 2 and 4}

The results reported in table 4.1 show that the variable earnings volatility EVOL is negative and statistically significant at $5 \%$ percent level for CAR1 $F$ only, which indicates that the firm whose earnings volatility is lower conveys the maximum information to investors about the future earnings and dividends of firms which as a result increase the stock prices and the returns. For the rest of the regressions we found no significant relationships between the earnings volatility and cumulative abnormal returns. The results reported in table 4.1, the coefficients of size variable SZE in all cases are statistically insignificant. Whatever the signal, we cannot make any conclusions from such results. The statistically significant and positive coefficient of the dividend yield DY for CAR2 $F$, at $5 \%$ level, indicates that after the dividend announcement the investor has good news and as a better event to respond, the stock prices have increased; as a result, the investors yield higher returns. In the case of CAR2 $\mathrm{P}$ and CAR4 $\mathrm{P}$, the coefficient is negative and significant at $5 \%$ level. It can be deduced that that investor feels bad about the dividends and predicts future dividends to be lower. As a result, the stock prices decline and affect the returns adversely. These results are consistent with Wansley et al. (1991); Lee \& Yan (2003); Gurgul et al. (2006); Dasilas \& Leventias (2011).

However, the Leverage variable LEV has a positive and significant coefficient for CAR2 P and CAR4, F at 5\% level, meaning that higher the debt ratio, the more the firm is willing to give healthy dividends; it could be interpreted in the signalling theory perspective that the firm being highly levered signals its value increasing which would obviously in return increase the firm profitability leading to healthy dividends. The liquidity ratio variable LIQ has positive and significant coefficients for CAR $1 F$ and CAR2 $\mathrm{F}$ at $5 \%$ level, which indicates that if the firm has sufficient liquid assets it would contribute to higher investors' wealth. In the case of CAR1 $P$ the coefficient is negative and significant at $5 \%$ level meaning that the firms having liquidity problems are less capable to pay dividends minimizing the shareholders wealth, so it could be inferred that the more liquid the firm is, the more finely it is positioned to announce dividends. The shareholders can pressure the management to do so in the case that 
the firm has free cash after investing in a project and vice versa in the case of low liquidity.

Table 4.2 Results of Multivariate Cross Sectional Regressions for CAR 6, 8 and 10

\begin{tabular}{|c|c|c|c|}
\hline \multirow[t]{2}{*}{ Variable } & \multicolumn{3}{|c|}{ CAR 6} \\
\hline & $\bar{F}$ & $\mathbf{P}$ & $\mathbf{N}$ \\
\hline \multirow[t]{2}{*}{ SZE } & -0.0020 & 0.0079 & -0.0246 \\
\hline & (0.1940 & $(0.6123)$ & $(0.2473)$ \\
\hline \multirow[t]{2}{*}{ EVOL } & -0.0023 & -0.0040 & 0.0077 \\
\hline & $(0.0311) * * *$ & $(0.5610)$ & $(0.1940)$ \\
\hline \multirow[t]{2}{*}{ DY } & 0.0247 & -0.6320 & 0.1820 \\
\hline & $(0.5012)$ & $(0.0583) * *$ & $(0.3924)$ \\
\hline \multirow[t]{2}{*}{ LEV } & 0.0222 & 0.0436 & -0.0412 \\
\hline & $(0.1621)$ & $(0.3456)$ & $(0.4481)$ \\
\hline \multirow[t]{2}{*}{ LIQ } & 0.0138 & -0.0440 & 0.0101 \\
\hline & $(0.6126)$ & $(0.3694)$ & $(0.4891)$ \\
\hline R2 & $37.88 \%$ & $8.23 \%$ & $33.71 \%$ \\
\hline $\begin{array}{l}\text { F-STAT } \\
\text { CHOW }\end{array}$ & 7.681 & $\begin{array}{c}1.926 \\
8.236 * * *\end{array}$ & 4.291 \\
\hline \multirow[t]{2}{*}{ Variable } & \multicolumn{3}{|c|}{ CAR 8} \\
\hline & $\mathbf{F}$ & $\mathbf{P}$ & $\mathbf{N}$ \\
\hline \multirow[t]{2}{*}{ SZE } & -0.0751 & 0.0056 & -0.0363 \\
\hline & $(0.3215)$ & $(0.4891)$ & $(0.2931)$ \\
\hline \multirow[t]{2}{*}{ EVOL } & -0.0039 & -0.0027 & 0.0037 \\
\hline & $(0.1352)$ & $(0.2218)$ & $(0.3215)$ \\
\hline \multirow[t]{2}{*}{ DY } & 0.0361 & -0.4310 & 0.0316 \\
\hline & $(0.0517)^{* *}$ & $(0.6145)$ & $(0.2340)$ \\
\hline \multirow[t]{2}{*}{ LEV } & 0.0351 & 0.0539 & 0.0378 \\
\hline & $(0.1863)$ & $(0.2371)$ & $(0.2712)$ \\
\hline \multirow[t]{2}{*}{ LIQ } & 0.0284 & -0.0036 & 0.0248 \\
\hline & $(0.2931)$ & $(0.1231)$ & $(0.1352)$ \\
\hline R2 & $41.21 \%$ & $9.23 \%$ & $36.45 \%$ \\
\hline $\begin{array}{l}\text { F-STAT } \\
\text { CHOW }\end{array}$ & 5.274 & $\begin{array}{c}1.642 \\
9.2163^{* * *}\end{array}$ & 3.218 \\
\hline \multirow[t]{2}{*}{ Variable } & \multicolumn{3}{|c|}{ CAR 10} \\
\hline & $\mathbf{F}$ & $\mathbf{P}$ & $\mathbf{N}$ \\
\hline \multirow[t]{2}{*}{ SZE } & -0.0914 & 0.0007 & -0.0086 \\
\hline & $(0.5610)$ & $(0.2579)$ & $(0.2340)$ \\
\hline \multirow[t]{2}{*}{ EVOL } & -0.0017 & -0.0073 & 0.0016 \\
\hline & $(0.1314)$ & $(0.2163)$ & $(0.2931)$ \\
\hline \multirow[t]{2}{*}{ DY } & 0.0614 & -0.4220 & 0.0763 \\
\hline & $(0.5610)$ & $(0.1940)$ & $(0.1352)$ \\
\hline \multirow[t]{2}{*}{ LEV } & 0.0637 & 0.0096 & 0.0516 \\
\hline & $(0.4618)$ & $(0.1523)$ & $(0.1455)$ \\
\hline \multirow[t]{2}{*}{ LIQ } & 0.0489 & -0.0084 & 0.0230 \\
\hline & $(0.1314)$ & $(0.2163)$ & $(0.2473)$ \\
\hline R2 & $38.26 \%$ & $6.13 \%$ & $23.43 \%$ \\
\hline F-STAT & 4.139 & 1.637 & 3.161 \\
\hline CHOW & & $7.856 * * *$ & \\
\hline
\end{tabular}

P-values are clustered in parenthesis*,** and*** indicates values at $10 \%, 5 \%$ and $1 \%$ significance level. F, P \& N in the second row of column are the Full, Positive and Negative CAR respectively. 
The chow test is reported in the bottom of table 4.1 and table 4.2 , which are presented to check the difference of the two groups with negative and positive CAR. The results reject the null hypothesis (the two groups are similar), which indicates that the information content of dividend is validated. In literature we find such evidence when the response of negative or positive CAR is not due to the firm-specific factors but due to the information content of dividend ( $\mathrm{j}$ in, 2000).

\subsection{Results of Multivariate Cross-Sectional Regressions for CAR 6, 8 and 10}

The results reported in table 4.2 show that the variable earnings volatility EVOL is negative and statistically significant at 5\% percent level for CAR6 $F$ only, which indicates that the firm whose earnings volatility is lower conveys the maximum information to investors about the future earnings and dividends of firms which as a result increases the stock prices and the returns. For the rest of regressions we found no significant relationship between the earnings volatility and cumulative abnormal returns. The statistically significant and positive coefficient of the dividend yield DY for CAR8, F at 5\% level indicates that the dividend announcement gives the investor good news as a better event to respond, and stock prices have increased as a result of the investor taking the high returns. In the case of CAR6 P and CAR4 P, the coefficient is negative and significant at $5 \%$ level. It can be deduced that that investor perceives the negative information about the dividends and predicts future dividends to be lower as a result, the stock prices declines and hence affect the returns adversely.

\section{Conclusion}

This paper investigates the information content of dividend by employing the event study methodology to check the effect of dividend announcement on stock returns. Furthermore, to check the relationship CAR with firm-specific factors, we employed the multivariate crosssectional regression keeping the CAR as the dependent variable. The three separate equations for categories of CAR for the whole sample, positive CAR and negative CAR are estimated. We report mixed results of the event study, the positive and significant effect of dividend information on some company returns, which seems to mean that the investors take this event as good news and we found an increasing trend of dividends. 
However, in some companies CAR is statistically negative and it seems that the dividend announcement has a negative impact on stock prices. The result of the multivariate cross sectional regression is mixed; however, the result of the chow test confirms that the information content of dividend holds for the sample companies for the given sample period of analysis and Pakistani companies respond positively to the dividend announcement as a whole. The results are in accordance with the studies conducted by several authors such as Wansley et al. (1991); Lee \& Yan (2003); Gurgul et al. (2006); Dasilas \& Leventias (2011).

The overall results incline us to reject the Miller \& Modigliani (1961) hypothesis which does not hold for Pakistani firms. The concepts of Jensen (1986) regarding free cash flow and Easterbrook (1984) for agency costs concept explain this phenomena in a much more understandable way: retention of free cash flows and over investment in projects could lead to a negative reaction creating a feeling of resentment in shareholders' minds or cause agency problems which might lead the managers to satisfy their own personal self interest in the form of perks and benefits, etc.

So far the results we reported clearly indicate the importance of dividend announcements on stock prices but still there are a lot of reasons which might affect these announcements in the form of stock splits, stock repurchases etc. These factors can be used as future directions of research heading this way.

\section{References}

Benartzi, S., Michaely, R. \& Thaler, R. (1997). Do Changes in Dividends Signal the Future or the Past? The Journal of Finance, 52(3), 1007-1034.

Borokhovich, K. A., Brunarski, K. R., Harman, Y. \& Kehr, J. B. (2005). Dividends, corporate monitors and agency costs. Financial Review, 40(1), 37-65.

Belden, S., Fister, T. \& Knapp, B. O. B. (2005). Dividends and directors: do outsiders reduce agency costs?. Business and Society Review, 110(2), 171-180. 
Bozos, K., Nikolopoulos, K. \& Ramgandhi, G. (2011). Dividend signaling under economic adversity: Evidence from the London Stock Exchange. International Review of Financial Analysis, 20(5), 364-374.

Boehme, R. D. \& Sorescu S. M. (2002). The Long-run Performance Following Dividend Initiations and Resumptions: Underreaction or Product of Chance?. the Journal of Finance, 57(2), 871-900.

Brav, A., Graham, J. R., Harvey, C. R. \& Michaely, R. (2005). Payout policy in the 21st century. Journal of Financial Economics, 77(3), 483527.

Bhattacharya, S. (1979). Imperfect Information, Dividend Policy, and "The Bird in the Hand" Fallacy. The Bell J ournal of Economics, 10(1), 259270.

Cooper M., Dimitrov O., Rau P. (2001). A Rose.com by Any Other Name. Journal of Finance, 56.

Dhanani, A. (2005). Corporate dividend policy: the views of British financial managers. Journal of Business Finance \& Accounting, 32(7-8), 1625-1672.

DeAngelo, H. \& DeAngelo, L. (2006). The irrelevance of the MM dividend irrelevance theorem. J ournal of Financial Economics, 79(2), 293-315.

Dyl, E. A. \& Weigand, R. A. (1998). The information content of dividend initiations: Additional evidence. Financial Management, 27-35.

Dasilas, A. \& Leventis, S. (2011). Stock market reaction to dividend announcements: Evidence from the Greek stock market. International Review of Economics \& Finance, 20(2), 302-311.

Easterbrook, F. H. (1984). Two agency-cost explanations of dividends. The American Economic Review, 74(4), 650-659.

Eades, K. M., Hess, P. J. \& Kim, E. H. (1985). Market rationality and dividend announcements. journal of Financial Economics, 14(4), 581-604.

Easton, S. A. \& Sinclair, N. A. (1989). The impact of unexpected earnings and dividends on abnormal returns to equity. Accounting \& Finance, 29(1), 1-19.

Fama, E. F. (1970). Efficient Capital Markets: A Review of Theory and Empirical Work. The Journal of Finance, 25(2), 383-417. 
Fama, E. F., Fisher, L., Jensen, M. C. \& Roll, R. (1969). The Adjustment of Stock Prices to New Information. International Economic Review, 10(1), 1-21.

Fargher, N. L. \& Weigand, R. A. (2009). Cross-sectional differences in the profits, returns and risk of firms initiating dividends. Managerial Finance, 35(6), 509-530.

Frankfurter, G. M. \& Wood J r, B. G. (2002). Dividend policy theories and their empirical tests. International Review of Financial Analysis, 11(2), 111-138.

Gordon, M. J. \& Shapiro, E. (1956). Capital equipment analysis: the required rate of profit. Management Science, 3(1), 102-110.

Grullon, G., Michaely, R. \& Swaminathan, B. (2002). Are Dividend Changes a Sign of Firm Maturity?*. The Journal of Business, 75(3), 387424.

Gurgul, H., Majdosz, P. \& Mestel, R. (2006). Implications of Dividend Announcements for the Stock Prices and Trading Volumes of DAX Companies.Czech Journal of Economics and Finance (Finance a uver), 56(1-2), 58-68.

How, J. C., Ngo, K. \& Verhoeven, P. (2011). Dividend initiations and longrun IPO performance. Australian J ournal of Management, 36(2), 267-286.

Healy, P. M. \& Palepu K. G. (1988). Earnings Information Conveyed by Dividend Initiations and Omissions. Journal of Financial Economics, 21, 149-175.

Jensen, M. (1986). Agency cost of free cash flow, corporate finance, and takeovers. Corporate Finance, and Takeovers. American Economic Review, 76(2).

Johnston, M. A. (2007). A review of the application of event studies in marketing. Academy of Marketing Science Review, 11(4), 1-31.

John, K. \& Williams, J. (1985). Dividends, Dilution, and Taxes: A Signalling Equilibrium. The Journal of Finance, 40(4), 1053-1070.

Jin, Z. (2000). On the differntial market reaction to dividend inititions. The Quaterly Review of Economics and Finance, 12, 263-277. 
Kao, C. \& Wu, C. (1994). Tests of Dividend Signaling Using the MarshMerton Model: A Generalized Friction Approach. The Journal of Business, 67(1), 45-68.

Kamstra, M. (2000). Fundamental Valuation of Zero-Dividend Firms. Simon Fraser University Department of Economics Working Paper.

Koch, A. S. \& Sun, A. X. (2004). Dividend changes and the persistence of past earnings changes. The Journal of Finance, 59(5), 2093-2116.

Lintner, J. (1956). Distribution of Incomes of Corporations Among Dividends, Retained Earnings, and Taxes. The American Economic Review, 46(2), 97-113.

Lee, B. S. \& Yan, N. A. (2003). The Market's Differential Reactions to Forward-Looking and Backward-Looking Dividend Changes. Journal of Financial Research, 26(4), 449-468.

Mougoué, M. \& Rao, R. P. (2003). The information signaling hypothesis of dividends: evidence from cointegration and causality tests. Journal of Business Finance \& Accounting, 30(3-4), 441-478.

Mitra, D. \& Owers, J. E. (1995). Dividend initiation announcement effects and the firm's information environment. Journal of Business Finance \& Accounting,22(4), 551-573.

Miller, M. H. \& Modigliani, F. (1961). Dividend Policy, Growth, and the Valuation of Shares. The J ournal of Business, 34, 411-433.

Miller, M. \& Rock, K. (1985). Dividend Policy Under Asymmetric Information. The Journal of Finance, 40(4), 1031-1051.

Nissim, D. \& Ziv, A. (2001). Dividend changes and future profitability. The J ournal of Finance, 56(6), 2111-2133.

Pettit, R. R. (1972). Dividend Announcements, Security Performance, and Capital Market Efficiency. The J ournal of Finance, 27(5), 993-1007.

Rubin, A. \& Smith, D. R. (2009). Institutional ownership, volatility and dividends. Journal of Banking \& Finance, 33(4), 627-639.

Rubinstein, M. (1976). The valuation of uncertain income streams and the pricing of options. The Bell J ournal of Economics, 407-425.

Ross, S. A. (1977). The determination of financial structure: the incentive-signalling approach. The Bell J ournal of Economics, 23-40. 
Shleifer, A. \& Vishny, R. W. (1986). Large shareholders and corporate control. The Journal of Political Economy, 461-488.

Thompson, R. (1985). Conditioning the return-generating process on firm-specific events: A discussion of event study methods. Journal of Financial and Quantitative Analysis, 20(2), 151-168.

Viswanath, P. V., Kim, Y. K. \& Pandit, J. (2002). Dilution, dividend commitments and liquidity: do dividend changes reflect information signaling?.Review of Quantitative Finance and Accounting, 18(4), 359379.

Watts, R. (1973). The Information Content of Dividends. The Journal of Business, 46(2), 191-211.

Wansley, J. W. (2009). Dividend change announcement effects and earnings volatility and timing. Journal of Financial Research, 14(1), 3749. 